\title{
Understanding Intra-organisational Information Dependency: An Empirical Network Analysis of Vietnamese Freight Forwarding Industry
}

\author{
Leon Teo \\ School of Business IT and Logistics, \\ RMIT University, Australia \\ E-mail: leon.teo@rmit.edu.au \\ Duy Dang-Pham \\ School of Business and Management, \\ RMIT Vietnam, Vietnam \\ E-mail: duy.dangphamthien@ rmit.edu.vn \\ Mathews Nkhoma \\ School of Business and Management, \\ RMIT Vietnam, Vietnam \\ E-mail: mathews.nkhoma@ rmit.edu.vn (Corresponding Author) \\ Thanh-Thuy Nguyen \\ Research Office \\ RMIT Vietnam, Vietnam \\ E-mail: thuy.nguyenthanh@rmit.edu.vn
}

\begin{abstract}
The use of timely, accurate, and relevant information is crucial for supply chain performance. Within business firms, executives and managers depend on demand and inventory data to make decisions for business operations. In this technological era, many firms are reliant on technological platforms to share mission critical information between their business units to prevent bullwhip effect due to information lag, and to improve coordination and collaboration among the units. Extant literature reveals that there is a strong research emphasis on information sharing practices between firms, and little on the information sharing practices within the firms for supply chain efficiencies. There is also limited research done to understand the impacts of information quality e.g. sharing mechanism, accuracy, timeliness and relevance have on the management of supply chains. Research often tend to focus on information sharing practices in modern businesses that utilises sophisticated IT systems for supply chain management, and neglects the business firms that operating in less developed environments. To investigate implications of information quality on supply chain efficiencies, this paper utilises social network analysis (SNA) to study information flows in the firms that operate in the Vietnamese freight forwarding industry.
\end{abstract}

Keywords: information exchange, information quality, bullwhip effect, supply chain performance, social network analysis, freight forwarding.

\section{INTRODUCTION}

Information sharing is an important driver for supply chain performance. Traditionally supply chain players only exchange orders-related information, but in this information age, technology allows firms to share demand and inventory data in real-time and inexpensively (Cachon \& Fisher, 2000). Demand information tends to be distorted and may not provide accurate information for upstream members for inventory management decisions. (Lee et al., 2004). The lack of information sharing between organisations also increases supply chain risks. Firms that are disengaged from information sharing practices risk often become the weakest link in their supply chains (Slone et al., 2007).

Existing literature has identified information sharing and quality as key contributors to supply chain performance. Li et al. (2006) suggests that level of information sharing encompasses quality and quantity aspects are both important due to their common inclusion as independent constructs in prior studies (Moberg et al., 2002). Other relevant constructs include relevancy, accuracy, and timeliness of information shared between players (Balsmeier \& Voisin, 1996). Despite the value of information for supply chain performance, little work has been done to investigate the level of information sharing impacts i.e. depth and sensitivity of information shared. Extant supply chain research emphasises on attributes of the individualistic entities such as firms and employees rather than their relational interactions, thus overlook the important structural effects (Borgatti \& Li, 2009).

This research proposes the use of SNA techniques to examine information sharing practices within business units of organisations for supply chain efficiency. The SNA 
techniques have been widely used in management to provide insights for organisational change and identification of key players within organisations that control resources including information flows (Borgatti et al., 2013).

\section{THE ROLES OF INFORMATION IN SUPPLY CHAINS}

Contemporary business are characterised by volatility and ever changing customer demands. Firms are forced to collaborate with their supply chain partners to maximise their competitive advantage (Marshall, 2015) and remain sustainable. Competition is not simply about individual firms but between different supply chains (Ha \& Tong, 2008).

Traditionally organisations are hierarchical, vertical and functionally defined. However, the dynamics of modern business environment require firms to be responsive and adopt a new paradigm for managing their supply chains. Industries are entering the era of "network competition" whereby "winners are organisations that can better structure, coordinate and manage the relationships with their partners in a network committed to delivering superior value in the final marketplace" (Christopher, 2011, p. 213). The understanding of information flows is also necessary for organisations to understand risk management (Christopher \& Lee, 2004), which has become one of most important area for business sustainability in recent years (Vanany et al., 2009).

Today's supply chain involves the effective and efficient management of material, information and transaction flows within the firms and also with their supply chain partners. (Rai et al. 2006). Also, achieving efficient flows within the supply chain involves a high level of "information openness" (Caglio \& Ditillo 2012) within the organisational business units (Lee et al., 2000). Information sharing is the exchange of important information, which may be commercially sensitive, to stimulate the collaboration between supply chain players (Cai et al., 2010, Li et al., 2014). Timely, accurate, and relevant information about demand and supply ensures that well-informed decisions could be made (Childerhouse \& Towill 2003). The exchange of information would also bring about supply chain costs reduction and improved responsiveness to customer needs. Other associated benefits include supply chain integration, increased customer satisfaction and improved quality (Li \& Lin, 2006).

With the adoption of the Internet and modern computing platforms such as EDI and ERP (White et al, 2005), the amount and quality of information shared across supply chains have increased vastly (Croson \& Donohue, 2006). Information related to inventory, replenishment, lead time, growth, demand, capacity, transactions can now be easily shared over the Internet (Li \& Lin, 2006, Cai et al., 2010). Information shared can be i). operational; ii). tactical; or iii). strategic nature and are elaborated as follow:

- Operational - allows for optimisation of production and replenishment activities (Rai et al., 2006, Narasimhan \& Nair, 2005);

- Tactical - allows for enhanced decision quality when interacting with other supply chain partners (Lee \& Whang, 2000; Wu et al., 2014);
- Strategic - allows for strategic planning to create competitive value and having an impact on the supply chain (Gunasekaran \& Ngai 2004; , Wu et al., 2014)

In addition, the effectiveness of information sharing is affected by a number of aspects such as timeliness, accuracy, adequacy and credibility ( $\mathrm{Li}$ et al., 2014). To promote sustainable supply chain relationships, supply chain members should adopt sharing practices that are "frequent, bidirectional, informal and non-coercive" (Cai et al., 2010). The lack of information sharing mechanisms within the supply chain results in information distortion (Lee et al., 2004), which further leads to the phenomena known as the "bullwhip effect".

\subsection{Information sharing and bullwhip effect}

The "bullwhip effect" (Lee et al., 2004) refers to the amplification of order variance in the upstream members in the supply chain due to the misuse or misunderstanding of demand information by the suppliers (Marshall, 2015). The lack of information sharing leads to the uncertainty among supply chain members about order variations, malfunctioning of machines, or delayed deliveries, which raises the need for keeping buffering inventories at all nodes in the same supply chain (Yu et al., 2001). This would result in excessive production and logistics costs, inefficient use of resources, and reduced profit margin (Yu et al., 2001; Marshall, 2015). Cronson \& Donohue (2006) suggested that causes of bullwhip effect in the supply chain can be operational (intra-organisational) and behavioural related. In their research, it was found that bullwhip effect also persists, but on a smaller magnitude, within organisations because decision-makers consistently underweighted the supply chain volumes.

Besides mitigating the bullwhip effect and its consequences, information sharing also assists the adoption of lean and just-in-time production (Ward \& Zhou, 2006), which prevents disruptions (Chopra \& Sodhi, 2004) and promotes agility (White et al., 2005). Businesses are gradually recognising the need agility in today's global economy to be competitive (Pujawan, 2004). Research has shown that manufacturers and retailers have experienced inventory and cost reductions through the use of EDI (electronic data interchanges). Other technologies such as ERP (Enterprise Resource Planning) systems have also encouraged information collaboration in the modern supply chain (White et al., 2005).

The adoption of IT platforms and the willingness to share commercially sensitive and strategic information provide structural mechanisms for innovative supply chain relationships (Fawcett et al., 2011). The sharing of information about demand between business units or functions (Chandra \& Kumar, 2000) ensures supply chain efficiency within a firm (Lee et al., 2000). Information sharing also improves collaboration within supply chains. Customer-supplier relationships can be nurtured through the exchange of information pertaining to "product development for new products, product improvements, costs, demand schedules (including point of sale data), and materials and supplies needed to meet production schedules" (Stock et al., 2000). Prior research suggested that manufacturers can achieve cost savings and inventory reduction with shared 
demand information (Lee et al., 2000).

In this new "era of network" competition, supply chain players are leveraging on information sharing and collaboration practices to maximise their competitive value and be agile (Christopher, 2011). Collaboration between suppliers and customers, through the use of IT, can also encourage the mutual development of organisational competencies or assets between the supply chain players (Paulraj et al., 2008). There has been an increased adoption of web-based applications that allow collection and analysis of information pertaining to the performance of supply chain players, which also provides access to the members' instant information (Chengalur-Smith et al., 2012). As global markets grow, competition is no longer restricted to domestic or individual businesses but rather between entire value (supply) chains (Horvath, 2001).

\subsection{Challenges for Information Sharing}

Since the millennium, there have been an increasing number of researches done on information sharing and collaboration due to the importance of information in supply chains (Marshall, 2015). Marshall suggests that information sharing research can be classified into four types: i) quality; ii) mechanism; iii) investment/implementation; and iv) type.

Despite the numerous information sharing research literatures, Marshall (2015) argues in his review that there are still areas that require attention such as information quality and mechanism. Likewise, our review of extant literature (of the last eight years) shows the literature on information sharing can be classified as in Table 1.

Table 1 Existing Research on Information Sharing

\begin{tabular}{|l|l|}
\hline Focus & Sources \\
\hline $\begin{array}{l}\text { Factors that } \\
\text { impact on } \\
\text { information } \\
\text { sharing }\end{array}$ & $\begin{array}{l}\text { Zhou et al. (2016); Marshall (2015); } \\
\text { Özer et al. (2011); Flynn et al. (2010); } \\
\text { Toni \& Nonino (2010); Cai et al. (2010); } \\
\text { Cantor \& Macdonald (2009); Fawcett et } \\
\text { al. (2008); Li \& Zhang (2008); } \\
\text { Ha \& Tong (2008) }\end{array}$ \\
\hline $\begin{array}{l}\text { Outcomes of } \\
\text { information } \\
\text { sharing }\end{array}$ & $\begin{array}{l}\text { Bian et al. (2014); Li et al. (2013); } \\
\text { Gallino \& Moreno (2014); Wu et al. } \\
\text { (2014); Li \& Ye (2013); Chengalur-Smith } \\
\text { et al. (2012); Barratt \& Barratt (2011); } \\
\text { Fawcett et al. (2011); Williams \& Waller } \\
\text { (2011); Chen \& Lee (2009); Kim et al. } \\
\text { (2009); Paulraj et al. (2008) }\end{array}$ \\
\hline $\begin{array}{l}\text { Drivers / } \\
\text { Barriers for } \\
\text { information } \\
\text { sharing }\end{array}$ & $\begin{array}{l}\text { (2012); Eckerd \& Hill (2012); Ha et al. } \\
\text { (2011); Toni \& Nonino (2010) }\end{array}$ \\
\hline
\end{tabular}

A word cloud analysis, with the use of Nvivo software, was performed on the recent literature review to identify the key research patterns and is presented as follows:

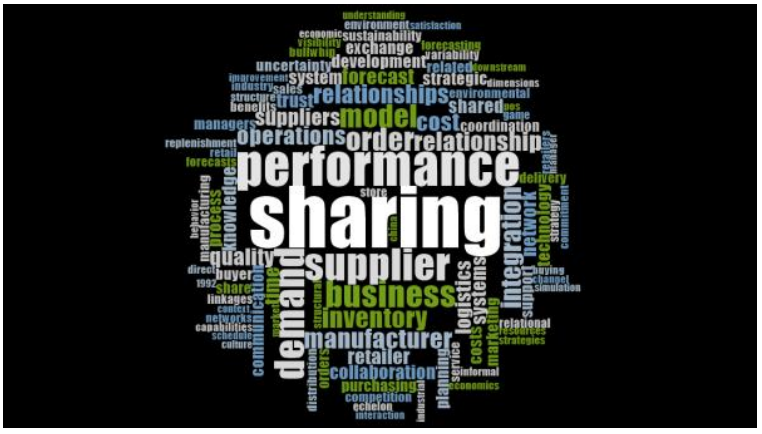

Figure 1 Word cloud analysis of existing literature

Our word cloud analysis suggests that a majority of prior research focused on the performance of supply chain and supplier as the key topics. Examples of key areas: relationship management with suppliers (Carr \& Kaynak, 2007), inventory management (Barratt \& Barratt, 2011), profit maximisation ( $\mathrm{Li} \&$ Zhang, 2008), flexibility and responsiveness (Wu et al., 2014).

It has been argued that the informal structure emerges as a crucial mean thanks to its flexibility and dynamism. Within a firm context, information sharing and collaborative activities were found to primarily happen informally rather than through formal channels (Morton et al., 2004, Toni \& Nonino, 2010). Although many companies have already established electronic systems such as ERP to integrate their business processes and data management, there are still many incidents whereby feral systems (Urus et al., 2011) are created to bypass formal information sharing mechanisms (Behren \& Sedara, 2004).

Despite the large numbers of supply chain information sharing articles, there is little mention of information quality within the current literature especially from an operational perspective e.g. information between business units/departments. Information quality can include: i) relevance; ii) accuracy; iii) timeliness; iv) completeness; v) coherence; vi) format; vii) accessibility; viii) compatibility; ix) security; and $\mathrm{x}$ ) validity. Although information sharing and quality are important aspects of supply chain management, it also depends on what, when, how, and with whom information is shared ( $\mathrm{Li} \& \mathrm{Lin}, 2006$ ).

To date, only a handful of research has address quality of information shared at the operational level and its implications on supply chain. Therefore this paper proposes the use of social network analysis (SNA) to address the following question:

- How SNA can be deployed to understand information sharing practices within supply chain firms?

\section{RESEARCH DESIGN}

Unlike the traditional approach that focuses on the individual's attributes, SNA research treats the interactions and relationships (termed "ties") between network actors (termed "nodes") as the main unit of analysis. This in turn allows researchers to directly examine the structural patterns of the relationship, as well as compute various network indices to evaluate the nodes' prominence (Otte \& Rousseau, 2002). 
The seminal article of Borgatti and Li (2009) suggested a number of network ties that are particularly meaningful and important in supply chain management context. For example, supply chain-related ties may include joint membership in trade association, task dependency, products and technology transfers at the firm-level (Borgatti \& $\mathrm{Li}$, 2009; Caglio \& Ditillo, 2012), or knowledge transfer and problem solving at the individual-level (Toni \& Nonino, 2010). Furthermore, the types of ties depend on the scope of the network research, such as focusing on the interactions and relationships between firms or people or both (Borgatti $\& \mathrm{Li}, 2009)$. As consistent with our research scope, the focal network type will describe information sharing between employees within their respective firm. The sampling population consisted of employees in freight forwarder companies in Vietnam. The online questionnaire was hosted on Qualtrics server and sent out to a list of companies in a database. After five months, we retrieved back 84 valid responses. SNA methods treat the network ties as the main unit of analysis instead of the actors (Borgatti et al., 2013). For our sample size of 84 respondents, the average number of ties was approximately 900 per network, which is sufficient for meaningful analysis.

The network questionnaire asks for the job function of the respondents in the company. Then, it asks the respondents to nominate their interactions with (1) the supplier, as well as other internal functions in the firm including: (2) procurement, (3) warehousing, (4) transportation, (5) finance/HR, (6) sales/marketing, (7) management, and (8) information technology. The questions aimed at capturing the exchange of information between the respondents and the eight supply chain functions listed above, by asking them to indicate which functions do they often seek/send information from/to and to what extent. For each function that they often exchange information with, the respondents were asked to rate the three dimensions of information's quality, namely accuracy, timeliness, and relevancy. Finally, we asked for the types of information that the respondents seek from the functions that they nominated.

The respondents were grouped together according to their function, and we took the median values of the nominated interactions (i.e. exchange of information; accuracy; timeliness; relevance) by groups of respondents belonging to the same function or business unit. The goal was to construct the networks of information sharing, as well as the evaluation of information's quality at the business unit level.

\section{FINDINGS AND DISCUSSION}

\subsection{Frequency of Information Exchange}

The analysis of the data reveals three clusters of information networks based on different frequencies of information exchange: i) daily; ii) weekly and iii) monthly basis. The daily exchange network (Figure 2) consisted of the business units of sales, procurement, warehousing and transportation, with operational transactional data exchange between them on a daily basis. The weekly information exchange (Figure 3) is management-warehousing centric and involves all business units. The monthly information exchange network (Figure 4) is finance-centric, and also involves all business units.

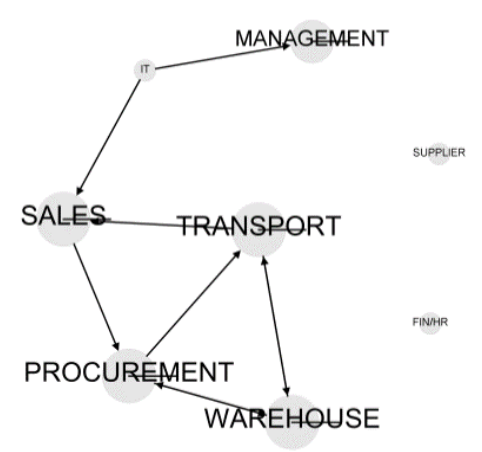

Figure 2 Daily Information Exchange Between Business Units

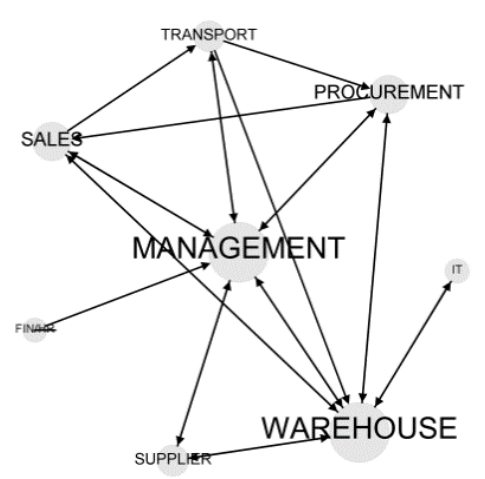

Figure 3 Weekly Information Exchange between Business Units

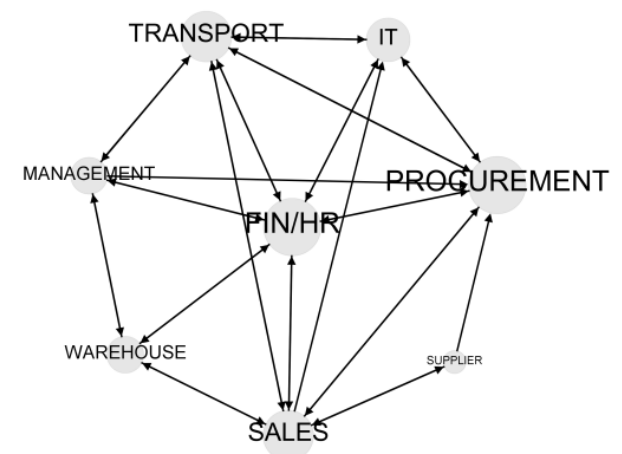

Figure 4 Monthly Information Exchange Between Business Units

\subsection{Accuracy of Exchanged Information}

Accuracy of the information exchanged by the networks also differed. The networks indicate that information provided by warehousing and sales is prone to inaccuracies (Figure 5). Also, all business units agreed that the information received from others within the same firm tend to be inaccurate and distorted Figure 6. However, most respondents agreed to huge extent that information received from management tend to be the most accurate as seen in Figure 7. 


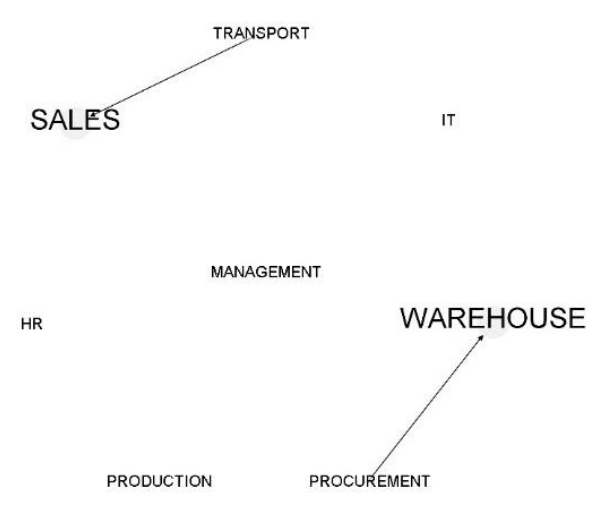

Figure 5 High Degree of Inaccurate Information (as Nominated by Other Units)

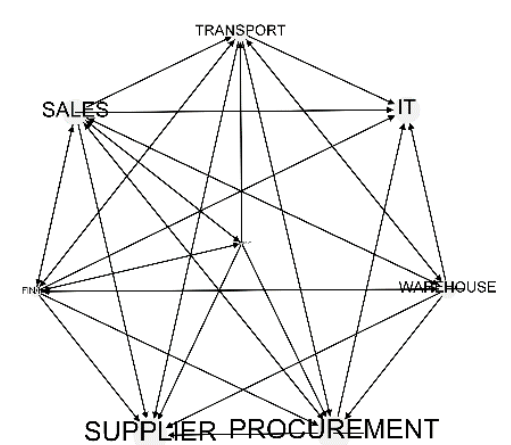

Figure 6 Some Degree of Inaccurate Information (as Nominated by Others)

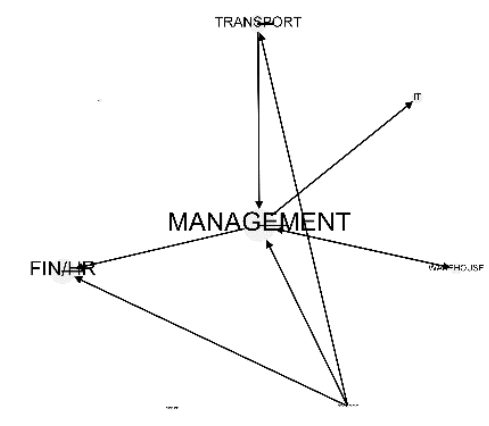

Figure 7 High Degree of Accurate Information (as Nominated by Others)

\subsection{Relevancy of Exchanged Information}

Our network analysis suggests that information exchanged within the firms tend to be highly unstandardized. Procurement has indicated that the information by their transportation counterparts tend to be improperly formatted and requires a lot of time and effort to clean up for their own use (Figure 8). Likewise, all business units involved in this study also agrees that the standards and relevance of the information exchanged within their firms are poor, and often requires manual manipulation and cleaning (Figure 9). However, the same analysis of information relevance also revealed that management and procurement information tend to be highly compatible for transport use (Figure 10).

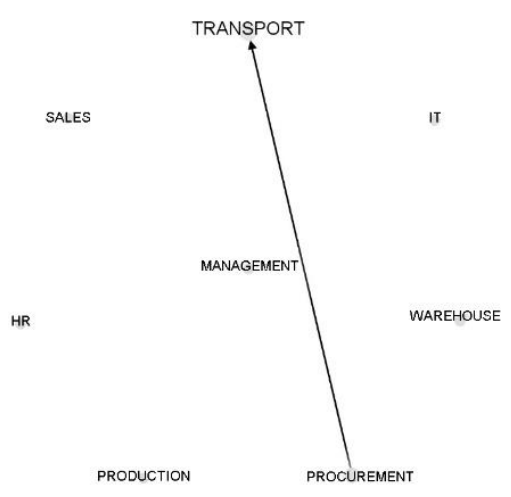

Figure 8 Most Effort Required to Clean and Interpret Data

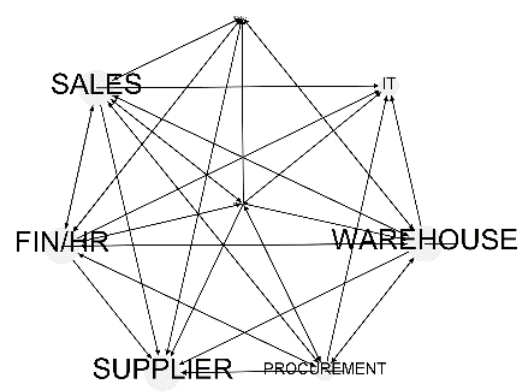

Figure 9 Some Effort Required to Clean and Interpret Data

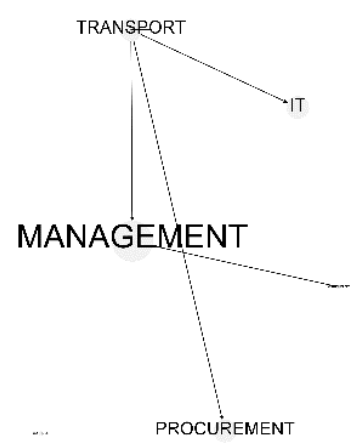

Figure 10 Minimum effort required to clean and interpret data

\subsection{Timeliness of exchanged information}

The responsiveness of the information provider differs for information networks. Among the business units, warehousing and production (Figure 11) tend to have longest delay when asked to provide information to other business units (including senior management). Transport, sales and IT units tend to be most prompt in providing information to their fellow colleagues. Transport and sales units (Figure 12) are capable of within same business day response, whereas IT (Figure 13) tend to be able to provide instant response. 


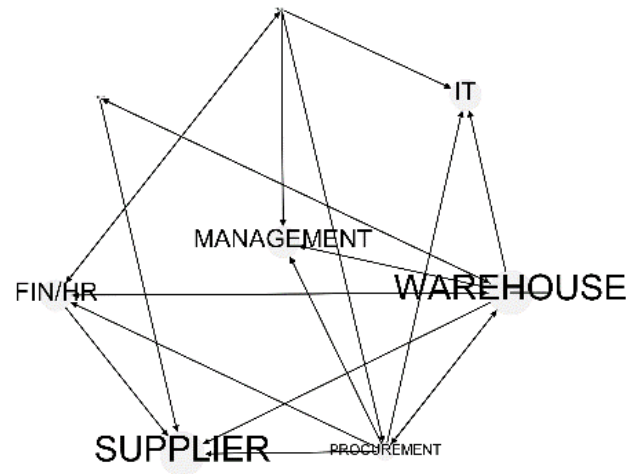

Figure 11 Most Delay in Providing Information

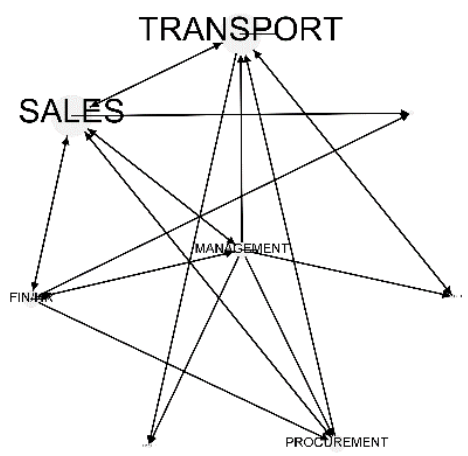

Figure 12 Some Delay in Providing Information TRANSPORT

SALES

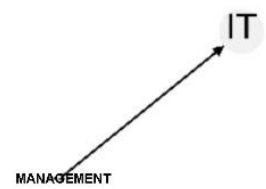

HR

\section{PRoDuction PROCUREMENT}

Figure 13 Least Delay in Providing Information

\subsection{Information infrastructure}

We have also observed that, the employees working in Vietnam freight forwarding firms are reliant on primitive technological tools such as email, chat applications / telephone, and fax to facilitate information exchanges. Only a small percentage of the respondents report the use of standardised software platforms such as ERP (12\%), EDI (42\%), CRM (13\%) and SRM (15\%).

\section{DISCUSSION}

Based on the findings that we have discussed previously, the key characteristics of the freight forwarding firms operating in Vietnam tend to be heavily reliant on manual processes for facilitating information exchange, without the use of standardised IT platforms. The identified networks of sharing information support that operational data is required by customer-centric business units (sales, transportation, procurement and warehousing) on a persistent and repeated basis. The communication of information among the business units in a firm is fundamental for supply chain efficiency and demonstrates the importance of internal integration (Won Lee et al., 2007).

Devaraj et al. (2007) argued that IT platforms are crucial for improving operational performance. In our analysis, recipients and users of warehousing and sales information found the obtained information is highly inaccurate. Due to the erroneous information dissemination, the users had to spend a lot of time and effort to clean, format, and standardise the obtained information for their use. Our analysis of information accuracy and relevance led to two similar networks (Figure 6 and Figure 9). These similar networks showed that information distortion within the freight forwarding firms was common, and this could be a result of the inaccurate data obtained from sales and warehousing, the two most important customer-centric business units. As with bullwhip effect, the consequences of information distortion tend to be most severe upstream (Chen et al., 2000; Croson \& Donohue, 2005). It could be observed from our network analysis that other business units that were reliant on sales and warehousing information would be impacted.

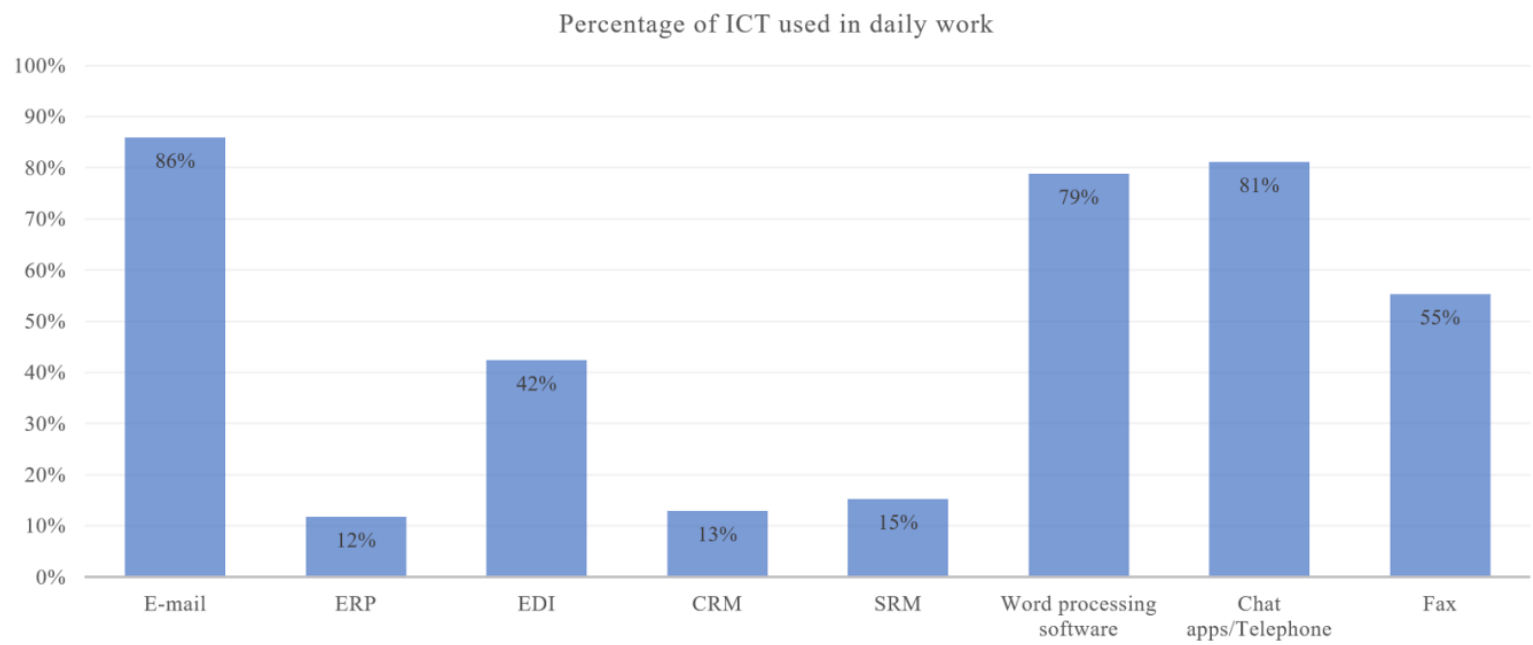

Figure 14 Percentage of ICT used in daily work 
Another main contributor to bullwhip effect is the leadtime of information (Van der Vors \& Beulens, 2002). In our timeliness network, it was found that supplier and warehousing tended to be most delayed for providing operational information to other business units. In our analysis of the nature of information sought by the business units, it became obvious that the warehousing information, especially inventory-related, was the most sought after by all other business units (Figure 11). It indicated the warehousing business unit tended to be overwhelmed by information requests from others within the firm, thereby reducing the responsiveness of the unit. On the other hand, non-management units such as sales, transportation, and procurement tended to perform relatively well, for the providence of operational information and often being able to reply within one business day.

A notable finding was that the quality of information originated from senior management was deemed timely and relevant by many respondents from other business units (Figure 7 and Figure 10). It indicated the management's strategic goals and instructions were well relayed to the business units, or there was an over-confidence in the quality of the information provided by the management.

The networks generated from the analysis also revealed the importance of warehousing units within the freight forwarding industry in Vietnam. Given that the role of freight forwarders is to arrange movement of inventories for their customers (Tongzon, 2009), it was not surprised that the quality of inventory-related information from warehousing and transportation units (as discussed in 4.5) affects the performance of the business operations. Transportation information such as lead time and location, as well as warehousing information such as inventory levels, are the necessary data needed by the executives to make business decisions and to ensure customer service.

Information quality is important to reduce the impacts of bullwhip effect (Chatfield et al., 2004; Li \& Lin, 2006). In our study of the players in the Vietnamese freight forwarding industry, we found that the industry to be technologically unsophisticated and highly dependent on instant messaging (chat applications), telephones, as well as emails for their information exchange. The lack of integrating IT platforms or software makes exchanging accurate and timely information challenging. Distorted or inconsistent information provided by the warehousing units were the main proponents of supply chain inefficiency and bullwhip effect.

It is important for the firms that are operating in the Vietnam freight forwarding industry to consider investing in information technological platforms such WMS (Warehousing Management System) or ERP system to increase the transparency and communication between the business units within firms. This will encourage the move from manual and laborious processes that the supply chain officers currently use to exchange information. The use of technological means to track inventory and data will also improve the information quality especially accuracy and formats, which will ultimately bring about better coordination among the business units and supply chain performance.

Our study has demonstrated the empirical use of SNA methods for analysing information sharing and quality within supply chain firms, especially at the business unit level. Future studies may consider conducting similar research at the individual level, which will enable investigation into the formal and informal sharing of information between employees in different departments. Doing so identify active information sharers and bottlenecks in the workplace and determine the characteristics of these key players. Qualitative methods such as case study or ethnography would be useful for exploring the causes of the disruptions in information sharing, as well as why informal information exchange occurs.

\section{CONCLUSION}

It has been well established that information sharing is an indispensable component for effective and efficient supply chains in today's competitive business world. As a result, there has been much research effort that focuses on different aspects of information sharing in supply chain, including the nature of information sharing (Rai et al. 2006) and information quality (Lee et al. 2013), the effects of information sharing on supply chain performance (Barratt \& Barratt, 2011), bullwhip effect caused by lack of information sharing (Lee et al. 2006), and mechanisms for improving information sharing (Barratt \& Barratt, 2011, ChengalurSmith et al., 2012).

This paper carried out a comprehensive literature review about information sharing in supply chain context since 2008. The literature review suggested that there is a limited number of empirical contributions focusing on the impacts of information quality and sharing mechanisms on supply chain performance despite their importance (Morton et al., 2004, Toni \& Nonino, 2010). This demands more empirical investigation and an appropriate research approach to explore in depth information quality and sharing mechanisms.

SNA methods were proposed to analyse information quality and sharing mechanisms, especially by leveraging the methods' strength that focuses on analysing in-depth information sharing as a network. We demonstrated the empirical use of SNA methods for such purpose, by exploring the information sharing and quality networks between business units in freight forwarding firms in Vietnam.

\section{REFERENCES}

Ashby, A., Leat, M., Hudson-Smith, M. (2012). Making connections: a review of supply chain management and sustainability literature. Supply Chain Management: An International Journal, 17(5), pp. 497-516.

Balsmeier, P. \& Voisin, W. (1996). Supply chain management: a time-based strategy. Industrial Management, 38, pp. 24-27.

Barratt, M. \& Barratt, R. (2011). Exploring internal and external supply chain linkages: Evidence from the field. Journal of Operations Management, 29, pp. 514-528.

Behrens, S. \& Sedera, W. (2004). Why do shadow systems exist after an ERP implementation? Lessons from a case study. PACIS 2004 Proceedings, p.136.

Bian, J. Guo, X. Lai, K. \& Hua, Z. (2014). The Strategic Peril of Information Sharing in a Vertical-Nash Supply Chain: A Note. International Journal of Production Economics, 158, pp. 37-43.

Borgatti, S. (2005). Centrality and network flow. Social Networks, 27(1), pp. 55-71.

Borgatti, S. Everett, M. \& Johnson, J. (2013). Analyzing Social 
Networks, Sage Publications Ltd.

Borgatti, S. \& Li, X. (2009). On social network analysis in a supply chain context. Journal of Supply Chain Management, 45(2), pp. 5-22.

Cachon, G. \& Fisher, M. (2000). Supply chain inventory management and the value of shared information. Management Science, 46(8), pp. 1032-1048.

Caglio, A. \& Ditillo, A. (2012). Opening the black box of management accounting information exchanges in buyersupplier relationships. Management Accounting Research, 23, pp. 61-78.

Cai, S. Jun, M. \& Yang, Z. (2010). Implementing Supply Chain Information Integration in China: The Role of Institutional Forces and Trust. Journal of Operations Management, 28, pp. 257-268.

Cantor, D. \& Macdonald, J. (2009). Decision-making in the supply chain: examining problem solving approaches and information availability. Journal of Operations Management, 27(3), pp. 220-232.

Carr, A. \& Kaynak, H. (2007). Communication methods, information sharing, supplier development and performance. International Journal of Operations \& Production Management, 27(4), pp. 346 -370.

Chandra, C. and Kumar, S., (2000). Supply chain management in theory and practice: a passing fad or a fundamental change?. Industrial Management \& Data Systems, 100(3), pp.100-114.

Chatfield, D.C., Kim, J.G., Harrison, T.P. and Hayya, J.C., (2004). The bullwhip effect-impact of stochastic lead time, information quality, and information sharing: a simulation study. Production and Operations Management, 13(4), pp. 340-353.

Chen, F., Drezner, Z., Ryan, J.K. and Simchi-Levi, D., (2000). Quantifying the bullwhip effect in a simple supply chain: The impact of forecasting, lead times, and information. Management Science, 46(3), pp. 436-443.

Chen, L. \& Lee, H. (2009). Information sharing and order variability control under a generalized demand model. Management Science, 55(5), pp. 781-797.

Chengalur-Smith, I. Duchessi, P. \& Gil-Garcia, J. (2012). Information sharing and business systems leveraging in supply chains: An empirical investigation of one web-based application. Information \& Management, 49, pp. 58-67.

Childerhouse, P. \& Towill, D. (2003). Simplified material flow holds the key to supply chain integration. OMEGA, 31(1), pp. $17-27$

Chopra, S. \& Sodhi, M.S. (2004). Managing risk to avoid supplychain breakdown. MIT Sloan Management Review, 46(1), p. 53.

Christopher, M. and Lee, H., (2004). Mitigating supply chain risk through improved confidence. International Journal of Physical Distribution \& Logistics Management, 34(5), pp. 388-396.

Christopher, M. (2011). Logistics and Supply Chain Management, 4th edn. Pearson, Great Britain.

Croson, R. \& Donohue, K. (2006). Behavioral Causes of the Bullwhip Effect and the Observed Value of Inventory Information. Management Science, 52(3), pp. 323-336.

Devaraj, S., Krajewski, L. and Wei, J.C., (2007). Impact of eBusiness technologies on operational performance: the role of production information integration in the supply chain. Journal of Operations Management, 25(6), pp.1199-1216.

Eckerd, S. \& Hill, J. (2012). The buyer-supplier social contract: information sharing as a deterrent to unethical behaviors. International Journal of Operations \& Production Management, 32(2), pp. 238-255.

Fawcett, S. Magnan, G. \& McCarter, M. (2008). A three-stage implementation model for supply chain collaboration. Journal of Business Logistics, 29(1), pp. 93-112.

Fawcett, S. Wallin, C Allred, C. Fawcett, A. \& Magnan, G. (2011). Information technology as an enabler of supply chain collaboration: A dynamic-capabilities perspective. Journal of Supply Chain Management, 47(1), pp. 38-59.

Flynn, B. Huo, B. \& Zhao, X. (2010). The impact of supply chain integration on performance: a contingency and configuration approach. Journal of Operations Management, 28(1), pp. 5871.

Gunasekaran, A. \& Ngai, E. (2004). Information systems in supply chain integration and management. European Journal of Operational Research, 159(2), pp. 269-295.

Ha, A. \& Tong, S. (2008). Contracting and Information Sharing Under Supply Chain Competition. Management Science, 54(4), pp. 701-715.

Ha, A. Tong, S. \& Zhang, H. (2011). Sharing demand information in competing supply chains with production diseconomies. Management Science, 57(3), pp. 566-581.

Hanneman, R. \& Riddle, M. (2005). Introduction to Social Network Methods. Riverside, CA: University of California, Riverside.

Horvath, L. (2001). Collaboration: the key to value creation in supply chain management. Supply Chain Management: An International Journal, 6(5), pp. 205-207.

Huang, Z. \& Gangopadhyay, A. (2004). A simulation study of supply chain management to measure the impact of information sharing. Information Resources Management Journal, 17(3), pp. 20-31.

Kim, Y. Yang, S. Hau, Y. Seo, J. \& Ghim, G. (2009). Identifying organizational knowledge paths through social network lens: Synthesis of multi-industry case studies. In System Sciences, 2009. HICSS'09. 42nd Hawaii International Conference on (pp. 1-10). IEEE.

Lee, H. Padmanabhan, V. \& Whang, S. (2004). Information distortion in a supply chain: The bullwhip effect Management Science, 50(12), pp. 1875-1886.

Lee, H. So, K. \& Tang, C. (2000). The value of information sharing in a two-level supply chain. Management Science, 46(5), pp. 626-643.

Lee, H. \& Whang, S. (2000). Information sharing in a supply chain. International Journal of Manufacturing Technology and Management, 1(1), pp. 79-93.

Li, L. \& Zhang, H. (2008). Confidentiality and information sharing in Supply chain coordination. Management Science, 54(8), pp. 1467-1481.

Li, S. \& Lin, B. (2006). Assessing Information Sharing and Information Quality in Supply Chain Management. Decision Support Systems, 42, pp. 1641-1656.

Li, S. Ragu-Nathan, B. Ragu-Nathan, T. \& Rao, S. (2006). The impact of supply chain management practices on competitive advantage and organizational performance. Omega, 34(2), pp. 107-124.

Li, Y. Ye, F. \& Sheu, C. (2014). Social Capital, Information Sharing and Performance: Evidence from China. International Journal of Operations \& Production Management, 34(11), pp. 1440-1462.

Marshall, D (2015). Assessing the Value of Supply Chain Information Sharing in the New Millennium. International Journal of Supply Chain Management, 4(4), pp. 10-21.

Moberg, C. Cutler, B. Gross, A. \& Speh, T. (2002). Identifying antecedents of information within supply chains. International Journal of Physical Distribution and Logistics Management, 32 (9), pp. 755-770.

Morton, S. Brookes, N. Smart, P. Backhouse, C. \& Burns, N. (2004), Managing the informal organisation: conceptual model, International Journal of Productivity and Performance Management, 53( 3), pp. 214-32.

Narasimhan, R. \& Nair, A. (2005). The Antecedent Role of Quality, Information Sharing and Supply Chain Proximity on Strategic Alliance Formation and Performance. International Journal of Production Economics, 96, pp. 301-313.

Otte, E. \& Rousseau, R. (2002). Social network analysis: a powerful strategy, also for the information sciences. Journal of Information Science, 28(6), pp. 441-453. 
Özer, Ö. Zheng, Y. \& Chen, K. (2011). Trust in forecast information sharing. Management Science, 57(6), pp. 11111137.

Paulraj, A. Lado, A. \& Chen, I. (2008). Inter-organizational communication as a relational competency: Antecedents and performance outcomes in collaborative buyers-suppliers relationships. Journal of Operations Management, 26, pp. 4564.

Pujawan, I. N., (2004). Assessing supply chain flexibility: a conceptual framework and case study. International Journal of Integrated Supply Management, 1(1), pp.79-97.

Rai, A. Patnayakuni, R. \& Seth, N. (2006). Firm performance impacts of digitally enabled supply chain integration capabilities. MIS Quarterly, 30(2), pp. 225-246.

Slone, R. Mentzer, J. \& Dittmann, J. (2007). Are you the weakest link in your company's supply chain?. Harvard Business Review, 85(9), p. 116

Stewart, G., (1997). Supply-chain operations reference model (SCOR): the first cross-industry framework for integrated supply-chain management. Logistics Information Management, 10(2), pp. 62-67.

Stock, G.N., Greis, N.P. and Kasarda, J.D., (2000). Enterprise logistics and supply chain structure: the role of fit. Journal of Operations Management, 18(5), pp. 531-547.

Tongzon, J.L., 2009. Port choice and freight forwarders. Transportation Research Part E: Logistics and Transportation Review, 45(1), pp. 186-195.

Toni, A. \& Nonino, F. (2010). The key roles in the informal organization: a network analysis perspective. The Learning Organization, 17(1), pp. 86-103.

Urus, S. Molla, A. \& Teoh, S. (2011). Post-ERP Feral System Taxonomy: A Manifestation From Multiple Case Studies. In European Conference on Information Management and Evaluation (p. 458). Academic Conferences International Limited.
Van der Vorst, J.G. and Beulens, A.J., 2002. Identifying sources of uncertainty to generate supply chain redesign strategies. International Journal of Physical Distribution \& Logistics Management, 32(6), pp. 409-430.

Vanany, I., Zailani, S. and Pujawan, N., (2009). Supply chain risk management: literature review and future research. International Journal of Information Systems and Supply Chain Management 2(1), pp. 16 - 33.

Ward, P. \& Zhou, H. (2006). Impact of information technology integration and lean/just-in-time practices on lead-time performance. Decision Sciences, 37(2), pp. 177-203.

White, A. Daniel, M. \& Mohdzain, M. (2005). The role of emergent information technologies and systems in enabling supply chain agility. International Journal of Information Management, 25(5), pp. 396-410.

Williams, B. \& Waller, M. (2011). Top-Down Versus Bottom-Up Demand Forecasts: The Value of Shared Point-of-Sale Data in the Retail Supply Chain. Journal of Business Logistics, 32(1), pp. 17-26.

Won Lee, C., Kwon, I.W.G. and Severance, D., (2007). Relationship between supply chain performance and degree of linkage among supplier, internal integration, and customer. Supply Chain Management: An International Journal, 12(6), pp. 444-452.

Wu, I.L. Chuang, C.H. Hsu, C.H. (2014). Information Sharing and Collaborative Behaviours in Enabling Supply Chain Performance: A Social Exchange Perspective. International Journal of Production Economics, 148, pp. 122-132.

Yu, Z. Yan, H. \& Cheng, T. (2001). Benefits of Information Sharing with Supply Chain Partnerships. Industrial Management \& Data Systems, 101(3), pp. 114-119.

Zhou, M. Dan, B. Ma, S. \& Zhang, X. (2016). Supply Chain Coordination with Information Sharing: The Information Advantage of GPOs. European Journal of Operation Research (2016): pp. 1-18.

Dr. Leon Teo graduated from RMIT University with a PhD that studied ERP implementations. Prior to his academia career, he has worked as a distribution manager in the fashion industry. Currently, he is employed as an associate lecturer at RMIT University who specialises in SCM and ERP subjects. His key research interests involve supply chain management, supply chain sustainability, omni-channel retailing and enterprise resource planning.

Duy Dang-Pham is completing his PhD (Business Information Systems) in the School of Business IT and Logistics, RMIT University, Australia. His research on behavioural information security and digital innovation issues, as well as the applications of social network analysis methods in these areas, has appeared in peer-reviewed journals such as Information and Management, Computers and Security, Information Systems Frontiers, Computers in Human Behavior and Business Horizons.

A/Prof Mathews NKhoma is an Associate Professor and current Head of School of Business and Management at RMIT Vietnam. A/Prof Nkhoma has published intensively in the areas of information security and management, and his work has appeared in academic journals in Australia, Germany, UAE, Malaysia, Vietnam, South Africa, the UK, and the US. He also has a track record of securing research funding including three RMIT University Program Development grants and five RMIT University research grants, totaling over $\$ 300,000$.

A/Prof Thanh-Thuy Nguyen is an Associate Professor and current Research Manager at RMIT Vietnam. A/Prof Nguyen has extensive work experience in the area of logistics and supply chain management, and she has also published intensively in these areas. She has a successful track record of securing research funding which includes the EU Horizon H2020 funding award in 2017. 